\title{
ANALISIS TINGKAT KETERBACAAN BUKU SISWA BAHASA INDONESIA KELAS VII BERBASIS KURIKULUM 2013
}

\author{
Gumono \\ gumono@unib.ac.id \\ Dosen pada Prodi Pendidikan Bahasa dan Sastra Indonesia, FKIP Universitas Bengkulu
}

\begin{abstract}
The aim of this research is to comprehensively describing readability of Bahasa Indoesia's students text book. The books is "Buku Siswa Bahasa Indonesia Kelas VII" revision edition 2014, published by Ministry of Education and Culture. Research was conducted with descriptive quantitative design. All of text in the text book (38 article) was taken as sample, and analysed using Fry Graph formula. The result of analysis shown, more than a half of all text (52\%) is suitable for seventh grade student. While, 18 text (48\%) is not suitable one.
\end{abstract}

Key words: text book, readability test, Kurikulum 2013, seventh grade.

\section{PENDAHULUAN}

Kurikulum 2013 merupakan
sebuah Kurikulum terbaru yang menawarkan sistem yang berbeda dari Kurikulum sebelumnya. Pembelajaran bahasa Indonesia dalam Kurikulum 2013 menempatkan teks sebagai basis dalam kegiatan pembelajaran. Kurikulum berbasis teks sudah menjadi istilah umum yang digunakan untuk menggambarkan Kurikulum 2013 pada mata pelajaran bahasa Indonesia. Peran teks yang sangat penting dalam Kurikulum 2013 bahasa Indonesia menyebabkan kegiatan membaca memiliki proporsi yang sama pentingnya dengan teks. Sebaik apapun isi teks tersebut akan percuma bila tidak dapat dibaca dengan baik oleh siswa.

Keberhasilan kegiatan membaca sangat berhubungan dengan kesesuaian keterbacaan teks tersebut terhadap pembacanya. Harjasujana (1996:106) mendefinisikan "keterbacaan merupakan ukuran tentang sesuai-tidaknya suatu bacaan bagi pembaca tertentu dilihat dari segi tingkat kesukaran atau kemudahan teksnya". Keterbacaan teks dalam buku siswa bahasa Indonesia Kurikulum 2013 sudah seharusnya mendapat perhatian penting dikarenakan peran teks yang cukup besar dalam kegiatan pembelajaran.

Pengukuran keterbacaan dapat dilakukan dengan berbagai macam cara. Salah satu cara yang populer digunakan adalah pengukuran dengan menggunakan formula keterbacaan. Formula tersebut antara lain Formula Fry, Formula Flesch, Fog Index, SMOG, dan lain-lain. Cara yang digunakan dalam penelitian ini adalah menggunakan formula keterbacaan Fry: Grafik Fry. Formula keterbacaan ini memberikan gambaran mengenai keterbacaan sebuah teks berdasarkan kelas-kelas. Kelas ini menggambarkan kelas pembacanya yaitu kelas 1 untuk siswa kelas 1, kelas 2 untuk siswa kelas 2, dan begitulah seterusnya. Dengan menggunakan konsep yang 
terbilang sederhana itu, penulis menganggap formula keterbacaan Fry: Grafik Fry lebih efisien untuk dipergunakan.

Berdasarkan uraian di atas, maka dilakukan penelitian untuk meneliti tingkat keterbacaan buku siswa kelas VII pada Kurikulum 2013. Buku siswa ini akan dianalisis menggunakan formula keterbacaan Fry sehingga, nantinya dapat diketahui betapa tingkat keterbacaan buku tersebut. Dengan melihat keterbacaan tersebut maka penulis dapat mengambil kesimpulan apakah buku siswa yang dikeluarkan oleh Kementrian Pendidikan dan Kebudayaan telah sesuai dengan kelas yang diperuntukkannya. Dengan keterbatasan yang dimiliki penulis maka penulis tidak menganalisis keseluruhan buku siswa Kurikulum 2013 yang dikeluarkan oleh Kementrian Pendidikan dan Kebudayaan. Penelitian akan dilakukan secara bertahap. Pada tahap ini penelitian akan dilakukan pada keterbacaan buku siswa kelas VII Kurikulum 2013 terbitan Kementrian Pendidikan dan Kebudayaan.

Sehubungan dengan hal tersebut, penelitian ini bertujuan untuk memperoleh gambaran mengenai tingkat keterbacaan teks-teks yang terdapat dalam buku Kurikulum 2013 yang diterbitkan oleh Kementrian Pendidikan dan Kebudayaan Republik Indonesia.

Membaca merupakan salah satu keterampilan berbahasa yang memiliki peran penting dalam Kurikulum 2013 yang berbasis teks. Melalui kegiatan membaca inilah informasi yang terdapat dalam teks pelajaran dapat diperoleh oleh siswa. Dengan pentingnya peran membaca tersebut, perlu dijelaskan mengenai definisi dari membaca secara jelas.

Pengertian membaca sangatlah beragam sehingga, untuk memperoleh pengertian yang tepat maka perlu dilakukan pengklasifikasian pengertian membaca. Berdasarkan pendapat Oka (1983:15) pengertian membaca secara garis besar dapat dibedakan sebagai berikut: 1) pengertian sempit yaitu pengertian yang menganggap membaca sebagai proses pengenalan simbolsimbol tertulis; 2) pengertian agak luas yaitu yang memuatkan pemahaman membaca pada makna atau isi bacaan saja; 3) pengertian luas yaitu terdapat adanya proses atau kegiatan memberikan reaksi kritis-kreatif terhadap bacaan. jika melihat dari pendapat tersebut maka membaca tidak dapat dipandang dalam pengertian yang sempit. Membaca haruslah diartikan dalam pengertian yang luas. Hal tersebut sejalan dengan pendapat Harjasujana (1996:5) memberikan pengertian membaca dalam 2 istilah yaitu, membaca merupakan kemampuan yang kompleks dan membaca merupakan interaksi pembaca dan penulis. Maksudnya kompleks adalah membaca bukanlah kegiatan memandangi lambang-lambang tertulis semata-mata. Bermacam-macam kemampuan dikerahkan oleh pembaca agar ia mampu memahami bacaannya.

Keterbacaan

(readability) merupakan kajian yang membahas tingkat kesukaran sebuah teks dilihat dari kesesuaian teks tersebut bagi pembaca. Menurut Harjasujana (1996:106), keterbacaan (readability) merupakan ukuran tentang sesuaitidaknya satu bacaan bagi pembaca tertentu dilihat dari tingkat kesukaran 
atau kemudahan teksnya. Jika mengacu pada pendapat tersebut maka dapat dikatakan keterbacaan sesungguhnya melihat kecocokan antara bahan bacaan dengan pembaca teks itu sendiri. Kecocokan tersebut dapat dilihat dari teks tersebut apakah teks tersebut terlalu mudah ataukah teks tersebut terlalu sulit untuk kelas pembaca tertentu.

Kegiatan

pengukuran

keterbacaan dapat dilakukan dengan berbagai macam cara. Menurut Gilliand (1972) (dalam Yasa 2013:239) "ada lima cara untuk menemukan keterbacaan teks, yaitu penilaian subjektif para ahli, metode tanya jawab, formula keterbacaan, carta, dan tes Cloze". Ada berbagai macam formula keterbacaan yaitu antara lain formula Fry, Formula Raygor, Formula Flesch, Fog Index, SMOG, dan lain-lain. Pengukuran menggunakan formula keterbacaan memiliki beberapa keterbatasan. Pengukuran formula keterbacaan yang mendasarkan pada struktur fisik atau permukaan menyebabkan konsep kandungan yang dimiliki teks menjadi kurang diperhatikan. Menurut Harjasujana (1996:109) rumusan formula keterbacaan yang sering digunakan dalam mengukur tingkat keterbacaan tidak memperhatikan unsur semantis. Akibat dari hal tersebut pengukuran keterbacaan pada teks berjenis sastra menjadi kurang maksimal. Pengukuran keterbacaan menggunakan formula keterbacaan bersifat perkiraan dan dimungkinkan adanya faktor lain yang mempengaruhi pemahaman siswa dalam membaca teks tersebut.

\section{METODE PENELITIAN}

Penelitian ini menerapkan metode deskriptif kualitatif. Pada penelitian ini, akan dilakukan pengukuran tingkat keterbacaan teks yang terdapat pada buku teks pelajaran Bahasa Indonesia untuk siswa kelas VII SMP. Pengukuran keterbacaan sebuah teks dapat dilakukan dengan beberapa macam cara. Cara-cara tersebut antara lain, penilaian subjektif para ahli, metode tanya jawab, formula keterbacaan, carta, dan tes Cloze. Tiap alat ukur keterbacaan yang telah disebutkan memiliki karakteristik dan cara pengukuran yang berbeda-beda. Pada penelitian ini formula pengukuran keterbacan yang diterapkan adalah Formula keterbacaan Fry. Formula keterbacaan Fry yang sering disebut Grafik Fry merupakan salah satu alat ukur keterbacaan yang diperkenalkan oleh Edward Fry. Tata cara penggunaan Formula Fry itu sendiri menurut Harjasujana (1996:116) antara lain sebagai berikut.

1) Dalam menghitung keterbacaan Formula Fry menggunakan seratus kata sebagai sampel tanpa memperhatikan panjangnya teks yang akan diteliti. Dengan demikian meskipun teks yang akan diteliti mencapai berlembar-lembar tetapi sampel yang diambil hanya seratus kata. Berikut gambaran mengenai Formula Fry. Perlu diperhatikan bahwa dalam mengambil sampel hendaklah memilih yang representatif artinya benar-benar mencerminkan teks bacaan. Kata yang dimaksud dalam hal ini menurut Harjasujana (1991:12) adalah kelompok lambang yang di kiri kanannya berpembatas. Maksud berpembatas di sini adalah sekelompok lambang dalam sebuah 
kalimat yang di awal dan di akhirnya dibatasi oleh spasi dan memiliki makna. Dengan demikian, Budi, IKIP, 1889 , =, masing-masing merupakan satu perkataan.

2) Hitunglah jumlah kalimat dari seratus buah kata tadi hingga perpuluhan terdekat. Maksudnya, jika kata yang terhitung 100 tidak jatuh di ujung kalimat maka akan dihitung dalam bentuk desimal (perpuluhan). Cara melakukan persepuluh adalah jumlah kata yang terhitung dalam 100 kata sampel dibagi dengan jumlah seluruh kata ada kalimat terakhir. Misalnya terdapat 12 kalimat dan pada kalimat terakhir bersisa 4 kata, maka kita hitung dahulu jumlah kata pada kalimat terakhir, misal 8. Masukan kedua angka tersebut dalam rumus yaitu 4/8 dan hasilnya adalah 0,5. Jumlahkan hasil tersebut ke dalam kalimat utuh tadi sehingga hasilnya 12,5 .

3) Setelah itu, hitunglah suku kata dari teks sampel 100 kata tadi. Untuk angka dan singkatan setiap kelompok lambang diperhitungkan sebagai satu suku kata. Pengukuran keterbacaan untuk bahasa Indonesia perlu dilakukan penyesuaian dengan mengalikan jumlah suku kata dengan angka 0,6.

4) Perhatikan grafik Fry. Kolom tegak lurus menunjukkan jumlah suku kata perseratus kata dan baris mendatar menunjukkan jumlah kalimat per satu kata. Pertemuan antara baris vertikal dan horizontal menunjukkan tingkatan-tingkatan kelas pembaca. Jika hasil pertemuan antara garis vertikal dan horizontal berada pada daerah gelap maka hasilnya tidak absah.
5) Tingkat keterbacaan ini bersifat perkiraan. Penyimpangan mungkin terjadi baik ke atas maupun ke bawah. Oleh karena itu peringkat keterbacaan hendaklah dikurangi satu atau ditambah satu. Maka dalam penelitian ini tingkat keterbacaan teks terebut harus berada pada tingkat 7 dan bisa mendapatkan penyimpangan 1 ke atas dan 1 ke bawah sehingga jika berada pada tingkat 6 atau 8 maka teks tersebut masih dapat diterima dan dikatakan memiliki keterbacaan yang sesuai.

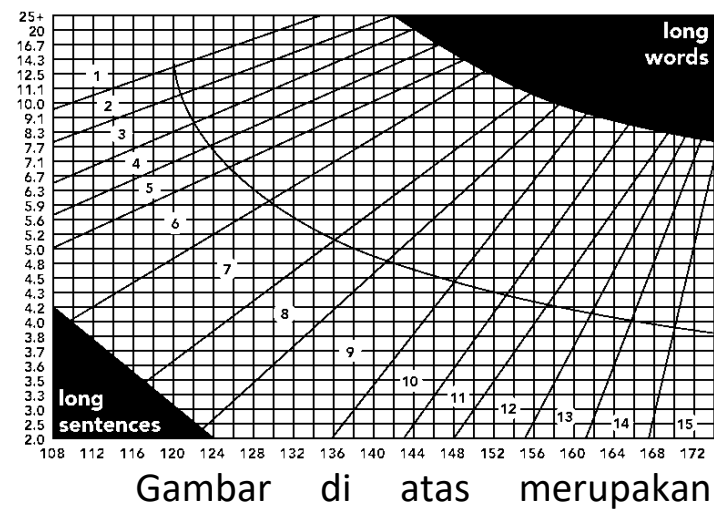
gambar grafik Fry yang dibuat oleh Edward Fry. Deretan angka-angka berikut: 108,112, 116, 120, 124, 128 dan seterusnya merupakan data jumlah suku kata perseratus. Di bagian samping kiri grafik terdapat angka 2.0, 2.5, 3.0, 3.5 dan seterusnya menunjukkan data ratarata jumlah kalimat perseratus perkataan. Hasil dari pengukuran data dimasukkan ke dalam grafik sesuai dengan posisinya masing-masing. Data yang telah dimasukkan di grafik jika ditarik garis lurus akan mempertemukan jumlah suku kata dan jumlah kalimat pada satu titik. Titik temu keduanyalah yang akan menjadi ukuran keterbacaan teks tersebut. Jika menunjukkan angka 1 , artinya teks tersebut cocok untuk pembaca dengan level peringkat baca 1 ; 
angka 2 untuk peringkat baca 2, angka 3 untuk peringkat baca 3 , dan seterusnya.

Daerah yang diarsir pada grafik yang terletak di sudut kanan atas dan di sudut kiri bawah grafik merupakan wilayah invalid, maksudnya jika hasil pengukuran keterbacaan teks jatuh pada wilayah gelap tersebut, maka teks tersebut kurang baik karena tidak memiliki peringkat baca untuk peringkat manapun.

\section{HASIL DAN PEMBAHASAN}

Kurikulum 2013 untuk mata pelajaran bahasa Indonesia merupakan Kurikulum berbasis teks. Hal tersebut dikarenakan pembelajaran bahasa Indonesia menjadikan teks sebagai orientasi dalam pembelajaran. Hal tersebut sesuai dengan pendapat Mahsun (2014:96) yang menyatakan bahwa satuan bahasa yang menjadi basis pembelajaran Kurikulum 2013 adalah teks. Inilah yang menjadikan perbedaan mendasar antara KTSP dan Kurikulum 2013. Pada KTSP pembelajaran dengan menggunakan teks belum mendominasi kegiatan pembelajaran.

Pemilihan teks sebagai basis pembelajaran dalam Kurikulum 2013 bukanlah tanpa alasan. Menurut Mahsun (2014:97) terdapat dua alasan mengapa teks dijadikan basis pembelajaran Kurikulum. Alasan tersebut yaitu pertama, melalu teks kemampuan berpikir siswa dapat dikembangkan; kedua materi pembelajaran berupa teks lebih relevan dengan karakteristik Kurikulum 2013 yang menetapkan capaian kompetensi siswa yang mencakup tiga ranah pendidikan: pengetahuan, keterampilan, dan sikap.
Penelitian dilakukan dengan mengambil seluruh judul teks yang terdapat dalam buku siswa yaitu sejumlah 38 teks. Tiap teks dalam buku tersebut merupakan teks yang jenisnya telah ditentukan dalam Kurikulum 2013. Meskipun teks-teks tersebut memiliki jenis yang berbeda, penulis mengukur keterbacaan tiap teks dengan menggunakan metode yang sama yaitu dengan formula Fry.

Menurut aturan dalam pengujian keterbacaan menggunakan grafik Fry, tingkat keterbacaan teks dapat dikatakan sesuai dengan kelasnya bila berada pada tingkat yang sama atau satu tingkat di bawah/atas. Tingkat keterbacaan teks yang sesuai untuk siswa kelas 7 adalah berada pada angka 6,7 , atau 8 sehingga teks tersebut dapat dikatakan sesuai untuk pembacanya.

Tingkat keterbacaan teks tersebut dapat dikelompokan dalam dua golongan yaitu teks dengan golongan sesuai dan tidak sesuai. Kelompok teks yang tidak sesuai memiliki dua golongan yaitu teks yang terlalu mudah dan teks yang terlalu sulit bagi siswa kelas VII. Penentuan jenis tersebut didasari pada tingkat keterbacaan teks tersebut yang bila berada di bawah standar yaitu 6,7 , dan 8 maka teks tersebut dapat digolongkan pada teks yang terlalu mudah. Begitu pula apabila teks tersebut bera pada tingkat di atas 6,7 , dan 8 maka digolongkan kepada teks yang terlalu sulit.

Teks-teks yang memiliki tingkat keterbacaan tidak sesuai dengan kelas pembacanya terdapat sebanyak 18 judul teks. Dari keseluruhan teks yang berjumlah 18 teks tersebut terdapat 1 judul teks yang teralu mudah dan 17 judul teks yang terlalu sulit. Lalu 20 judul 
teks selebihnya merupakan teks yang memiliki keterbacaan sesuai. Persentase kesesuainya digambakan dalam diagram berikut.

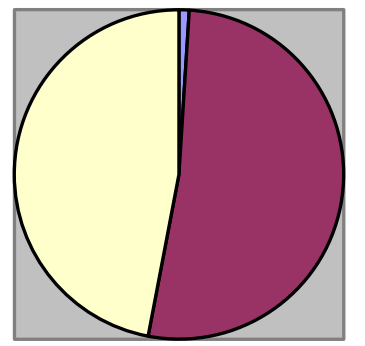

$\square$ Mudah

$\square$ Sesuai

口Sukar

Penelitian ini memberikan gambaran bahwa setengah dari keseluruhan teks yang terdapat dalam buku siswa bahasa Indonesia Kurikulum 2013 memiliki tingkat keterbacaan yang sesuai dengan kelas pembacanya. Dengan begitu setengah dari keseluruhan judul teks-teks tersebut memiliki tingkat keterbacaan yang tidak sesuai dengan kelas siswa. Teks-teks yang memiliki tingkat keterbacaan yang tidak sesuai dengan kelas pembaca memiliki dua jenis yaitu teks dengan keterbacaan yang terlalu mudah dan teks dengan keterbacaan terlalu sulit.

Jumlah keseluruhan teks yang memiliki keterbacaan sesuai adalah sebanyak 20 judul teks. Salah satu teks yang memiliki keterbacaan sesuai adalah teks yang berjudul "Tsunami". Pada teks tersebut setelah diambil sampel 100 kata terdapat jumlah suku kata sebanyak 151 suku kata dan terdapat 7,7 kalimat. Berikut kutipan teks tersebut.

Gelombangnya yang besar menyebabkan banjir dan kerusakan saat menghantam pantai. Tsunami tercipta saat permukaan dasar laut bergerak naik turun di sepanjang patahan selama gempa terjadi. Patahannya menyebabkan keseimbangan air menjadi terganggu. Makin besar daerah patahan yang terjadi, makin besar pula tenaga gelombang yang dihasilkan. Selain itu, tsunami juga tercipta karena meletusnya gunung berapi yang menyebabkan pergerakan air di laut atau perairan sekitarnya sangat tinggi. Gelombang yang besar menyebabkan banjir dan kerusakan saat menghantam pantai. Gelombang tsunami yang terjadi di laut melaju lebih cepat daripada gelombang normal. Gelombang tersebut menyebar ke segala arah dengan ketinggian 30 sampai dengan 50 meter.

Dari teks tersebut dapat diperhatikan bahwa la memiliki kalimat yang tidak terlalu kompleks. Kalimat yang tidak terlalu kompleks mempermudah siswa dalam memahami kalimat tersebut. Penggunaan istilah dalam teks tersebut juga telah sesuai untuk perkembangan siswa. Istilah yang dipergunakan merupakan istilah yang umum dan cukup akrab didengar oleh siswa.

Dengan pemilihan teks yang sesuai seperti dicontohkan di atas akan menjadikan kegiatan pembelajaran lebih efektif. Hal tersebut terjadi karena keterbacaan teks yang sesuai dapat menghindari rasa depresi dan bosan dari siswa saat sedang membaca. Atas dasar itulah keterbacaan teks menjadi hal yang perlu diperhatikan dalam kegiatan pembelajaran yang menggunakan teks.

Terdapat juga 19 judul teks dari 38 teks yang memiliki tingkat keterbacaan yang tidak sesuai dengan siswa kelas VII. Dari 20 judul terebut terdapat 6 judul teks yang memiliki tingkat keterbacaan di bawah standar. Salah satu contoh dari teks yang memiliki keterbacaan di bawah standar adalah teks dengan judul "Ikan Hias Yang Digemari" dalam teks tersebut dapat 
terlihat bahwa teks tersebut memiliki 139 suku kata dan 10,2 kalimat dalam 100 kata. Kutipan 100 kata dari teks tersebut sebagai berikut.

Ikan adalah binatang bertulang belakang yang hidup di air dan bernafas dengan insang. Di antara ikan-ikan itu ada yang fungsinya sebagai hiasan. Ikan hias ini ada yang berasal dari air asin (laut) dan air tawar. Ada lima jenis ikan air tawar yang banyak digemari, yakni ikan Cupang, ikan Manfish, dan ikan Discuss. Ikan cupang adalah jenis ikan kecil yang cantik. Ikan hias ini sangat dikenal masyarakat Indonesia, khususnya anak-anak. Ikan ini terkenal akan kecantikannya. Ada yang berwarna biru, dan ada yang berwarna ungu. Ikan ini cantik karena ekornya mengembang. Sayangnya, ikan ini agresif sehingga tempat penyimpanannya harus tersendiri.

Terlihat bahwa teks tersebut memiliki kalimat yang cukup pendek. Mengacu pada pendapat Kintsch \& Miler yang menyatakan bahwa kalimat yang panjang akan lebih sulit diingat daripada kalimat yang pendek, hal inilah yang terjadi jika kalimat tersebut terlalu mudah maka akan membuat keterbacaan teks tersebut cocok untuk siswa sekolah dasar kelas $\mathrm{V}$ bukan pada kelas VII. Penyesuaian tingkat keterbacaan perlu dilakukan demi kepentingan siswa yang akan membaca buku tersebut. Selain dapat menimbulkan rasa bosan, pemberian teks pada tingkatan yang lebih mudah dari kelas siswa tersebut akan menyebabkan turunnya kemampuan membaca siswa. Hal tersebut dapat terjadi dikarenakan siswa terbiasa membaca teks yang memiliki keterbacaan mudah sehingga saat menemui teks yang berada pada kelasnya ia mengalami kesulitan. Dampak buruk seperti ini perlu diantisipasi sehingga kualitas kemampuan membaca siswa dapat meningkat seperti seharusnya.

Lalu terdapat 17 judul teks yang berada pada tingkatan yang lebih sulit dari siswa kelas VII. Dikatakan demikian karena grafik Fry menunjukkan angka keterbacaan teks tersebut berada di atas standar keterbacaan untuk siswa kelas VII. Salah satu judul yang menunjukkan tingkat keterbacaan yang terlalu sulit adalah teks dengan judul "Sitiri Pesawat Tanpa Awak, Ciptaan Indonesia" yang memiliki jumlah suku kata sebanyak 1623 dan jumlah kalimat 3,9. Jika diperhatikan berdasarkan data di atas teks tersebut memiliki rata-rata kalimat yang cukup panjang. Hal tersebut berimbas pada daya ingat siswa.

Teks yang berjudul "Sriti Pesawat Tanpa Awak, Ciptaan Indonesia" berdasarkan grafik Fry menempati tingkat 13 yang berarti teks tersebut sesuai untuk kelas mahasiswa. Berikut kutipan dari teks tersebut.

Dalam fungsinya, pesawat tersebut dapat digunakan mengintai kegiatan-kegiatan para teroris yang banyak dilakukan di dalam hutan terpencil yang susah dijamah oleh transportasi darat, illegal logging, kebakaran hutan sampai dengan pencurian ikan di wilayah tertentu oleh orang asing. BPPPT (Badan Pengkajian dan Penerapan Teknologi) yang merupakan salah satu lembaga teknologi milik pemerintah memperkenalkan pesawat tanpa awak hasil rancangannya yang diberi nama SRITI. Pengembang mengatakan bahwa pesawat Sriti ini asli 100 persen buatan anak bangsa, karena 
proses dari awal sampai akhirnya dilakukan oleh anak bangsa. Sriti, rencananya akan digunakan oleh lembaga pengawas laut, hutan dan gunung untuk membantu pekerjaan mereka memantau aktivitas-aktivitas....

Tingkat kesulitannya tidak hanya terlihat dari panjang kalimat yang dimilikinya tetapi juga pada tingkat kata. Kata yang dipergunakan banyak yang merupakan kata yang cukup sulit seperti "nir-awak", "stainless", "catapult take off" dan lain-lain. Berdasarkan data tersebut tidak mengherankan bila teks tersebut memiliki tingkat keterbacaan yang sesuai dengan kelas mahasiswa.

Keterbacaan yang terlalu sulit membuat siswa kesulitan dalam mengingat kalimat yang terlalu panjang. Ditambah lagi dengan banyaknya kosakata sulit membuat terhambatnya kegiatan membaca siswa. Hal tersebut dapat membuat siswa memadai frustrasi dan memutuskan berhenti untuk membaca. Bila hal tersebut berlanjut tidak menutup kemungkinan menyebabkan siswa menjadi mala membaca karena ia telah berpikir bahwa membaca merupakan kegiatan yang sulit.

Untuk mendapat hasil yang lebih akurat maka penulis melakukan penelitian pada teks yang berjudul "Sitiri Pesawat Tanpa Awak, Ciptaan Indonesia" dengan menggunakan formula keterbacaan lain sehingga dapat dilihat perbandingannya. Teks tersebut dipilih karena memiliki keterbacaan yang sangat jauh berada di atas kelas pembaca buku tersebut. dari pengukuran menggunakan grafik Raygor diperoleh data jumlah kalimat sebanyak 3,9 kalimat dan 53 kata sulit. Data tersebut dimasukkan ke dalam grafik Raygor dan menghasilkan keterbacaan invalid yang artinya tidak sesuai terhadap tingkat manapun. Hal tersebut menunjukkan bahwa teks tersebut belum layak digunakan untuk kegiatan pembelajaran.

Permasalahan keterbacaan ini haruslah mendapatkan perhatian dalam dunia pendidikan. Terlebih lagi saat ini teks telah menjadi basis dalam pembelajaran bahasa Indonesia di Kurikulum 2013. Dengan menggunakan teks pembelajaran bahasa Indonesia membuat kegiatan membaca menjadi hal yang sangat utama. Dapat dibayangkan bila teks yang harusnya membantu siswa belajar justru menjadi penghambat bila salah memilihnya.

Teks pelajaran haruslah memiliki keterbacaan yang disesuaikan dengan tiap tingkatan siswa. Dengan terus memberikan teks yang sesuai dengan perkembangan siswa, kegiatan pembelajaran dapat berjalan lancar. Selain itu hal tersebut juga dapat membantu perkembangan siswa dalam membaca. Perkembangan membaca siswa berjalan lancar karena keterbacaan teks yang diberikan terus bertingkat secara bertahap. Hal itulah yang membuat siswa berkembang secara bertahap pula.

\section{SIMPULAN}

Setelah dilakukan penelitian mengenai tingkat keterbacaan buku siswa bahasa Indonesia SMP kelas VII terbitan Kementerian Pendidikan dan kebudayaan Republik Indonesia maka, dapat disimpulkan bahwa dari 38 judul teks, terdapat 20 (52\%) judul teks yang memiliki keterbacaan yang sesuai dengan siswa kelas VII SMP dan sebanyak 18 (48\%) judul teks memiliki 
keterbacaan yang tidak memenuhi syarat. Hal tersebut menunjukkan bahwa lebih dari setengah dari jumlah keseluruhan teks dalam buku tersebut yang memenuhi syarat.

Jumlah keseluruhan dari teks yang memiliki keterbacaan sesuai dengan siswa kelas VII yaitu sejumlah 20 judul teks. Teks yang memiliki keterbacaan tidak sesuai dapat digolongkan menjadi dua jenis yaitu teks yang terlalu mudah dan teks yang terlalu sulit. Teks dengan tingkat keterbacaan yang terlalu mudah memiliki jumlah sebanyak 1 judul teks. Untuk teks yang memiliki tingkat keterbacaan yang terlalu sulit sebanyak 17 judul teks.

\section{DAFTAR PUSTAKA}

Alek dan Achmad. 2011. Bahasa Indonesia untuk Perguruan Tinggi. Jakarta: kencana.

Ariyanti, Lise. 2001. Analisis Keterbacaan Buku Teks Bahasa Indonesia Untuk SLTP Bengkulu Berdasarkan Fog Indeks. Skripsi. Bengkulu: Fakultas Keguruan dan Ilmu Pendidikan Universitas Bengkulu.

Hafni. 1981. Pemilihan dan Pengembangan Bahan Pengajaran Membaca. Jakarta: P3G Departemen Pendidikan dan Kebudayaan.

Hanafi.2011. Metodologi Penelitian Bahasa Untuk Penelitian, Tesis \& Disertasi. Jakarta: Diadit Media.

Harjasujana, Akhmad Slamet dan Yeti Mulyanti. 1996. Membaca 2. Jakarta: Departemen Pendidikan dan Kebudayaan.
Harjasujana, Akhmad Slamet, Yeti Mulyanti, dan Encep Kusumah. 1991. Pokok-pokok Materi Membaca dan Pengajarannya. Bahan Ajar. Bandung: Kursus Pendalaman Materi BSBI IKIP Bandung.

Kementrian Pendidikan dan Kebudayaan. 2014. Bahasa Indonesia Wahana Pengetahuan Edisi Revisi. Jakarta: Pusat Kurikulum dan Pembukuan, Balitbang, Kemendikbut.

Mahsun. 2014. Teks Dalam Pembelajaran Bahasa Indonesia Kurikulum 2013. Jakarta: PT Raja Grafindo Persada.

Oka, I Gusti Ngurah. 1983. Pengantar Membaca \& Pengajaranya. Surabaya: Usaha Nasional.

Priatni, Endah tari. 2014. Desain Pembelajaran Bahasa Indonesia Dalam Kurikulum 2013. Jakarta: PT Bumi Aksara.

Sudarianto. 1988. Metode Linguistik. Yogyakarta: Gajah Mada University Press.

Sugiyono. 2012.Metode Penelitian Pendidikan (Pendekatan Kuantitatif, Kualitatif, dan R\&B). Bandung: Alfabeta.

Supriadi, Dedi. 2001. Anatomi Buku Sekolah di Indonesia : Problematika Penilaian, Penyebaran, dan Penggunaan Buku Pelajaran, Buku Bacaan, dan Buku Sumber. Yogyakarta: Yayasan Adikarya Ikapi dan The Ford Foundation. 
Susetyo. 2010. Penelitian Kuantitatif dan Penelitian Tindakan Kelas. Bahan Ajar. Bengkulu: PSPBSI JPBS FKIP Universitas Bengkulu.

Yasa, Ketut Ngurah. 2013, Kecermatan Formula Keterbacaan Sebagai Penentu Keefektifan Teks. Jurnal Pendidikan dan Pengajaran, Jilid 46 nomor 3: 238-245, Oktober. http://ejournal.undiksha.ac.id/in dex.php/JPP/article/view/4226 di akses pada 15 November 2015.

Yasa, KN, Sutama Made, dan Mitha Nengah. 2013. Kecermatan Formula Flesch, Fog Index, Grafik Fry, SMOG, dan BI Sebagai Penentu Keefektifan Teks Berbahasa Indonesia. http://pasca.undiksha.ac.id/ejournal/index.php/jurnal_bahasa /article/view/516 di akses pada 15 November 2015. 